\title{
Identification of Flexibacter maritimus or Tenacibaculum maritimum from post-larvae of Litopenaeus vannamei ?. Comment on Mouriño et al. (2008)
}

\author{
Avendaño-Herrera, $R$.* \\ Laboratorio de Veterquímica, \\ Camino Melipilla 5641, Cerrillos, Santiago, Chile \\ *e-mail: reavendano@yahoo.com
}

Received July 28, 2008 - Accepted July 31, 2008 - Distributed February 28, 2009

Recently, Mouriño et al. (2008) reported the first record in Brazil of the filamentous bacteria Flexibacter maritimus (Wakabayashi et al., 1986) from the hatching of Litopenaeus vannamei post-larvae (Boone, 1931). In our view, a generalized lack of clarity about this identification has occurred and the discussion of some issues raised in the work is beyond the scope of this commentary.

As Mouriño et al. argued, the identification of this isolate as F. maritimus was influenced by the tests of Wakabayashi et al. (1986) and Chen et al. (1995), who had misclassified this microorganism within the Flexibacter genus. In fact, Suzuki et al. (2001), in a phylogenetic analysis and taxonomic study, demonstrated that Flexibacter maritimus is distantly related to Flexibacter flexilis, the type species of the genus Flexibacter. Therefore, Suzuki et al. (2001) concluded that this strain constitutes a new bacterial species in the genus Tenacibaculum, distinct from $F$. maritimus, named T. maritimum. Fourteen members are currently classified within this genus, including
T. litopenaei isolated from shrimp in Taiwan (Sheu et al., 2007). Therefore, to avoid confusion with other bacteria, this note will use the name T. maritimum.

Even though the bacterium reported by Mouriño et al. (2008) could be T. maritimum, one of the major constraints on the detection of this pathogen is the lack of methods to distinguish this microorganism from others that are phenotypically similar and phylogenetically related species, particularly those of the genus Flavobacterium and Cytophaga (Suzuki et al., 2001). The morphological, physiological and biochemical characteristics useful in the identification of Tenacibaculum maritimum have been detailed by several authors (see review Avendaño-Herrera et al., 2006a), and must contain at least a limited number of data (see Table 1). However, as Mouriño et al. show in their paper, only thirteen biochemical assays were done to propose T. maritimum as the cause of massive mortality of L. vannamei post-larvae. Some of these tests are not necessary for the identification of this pathogen as growth on

Table 1. Biochemical characteristics of filamentous bacteria in Litopenaeus vannamei and Tenacibaculum maritimum reference strains. Data are from Wakabayashi et al. (1986), Gosink et al. (1998), Suzuki et al. (2001) and Avendaño-Herrera et al. (2004a). +, positive; -, negative; W, weakly positive; ND, not determined; NG, no growth in the presence of NaCl. These bacteria are Gram-negative, rod-shaped and positive for catalase and oxidase.

\begin{tabular}{|c|c|c|}
\hline Characteristic & Isolated strain & Tenacibaculum maritimum $(\mathrm{n}=2)$ \\
\hline Origin & Post-larvae of shrimp, Brazil & $\begin{array}{l}\text { Diseased red sea bream } \\
\text { fingerling, Japan }\end{array}$ \\
\hline $\begin{array}{l}\text { Cells size }(\mu \mathrm{m}) \\
\text { Colony morphology }\end{array}$ & $15 \times 0.4-0.5$ & $2-30 \times 0.5$ \\
\hline Shape & Rhizoid & Uneven edge \\
\hline Colour & Creamy & Pale yellow \\
\hline Gliding motility & ND & + \\
\hline Congo red absorption & + & + \\
\hline Flexirubin pigment & ND & - \\
\hline Temperature range $\left({ }^{\circ} \mathrm{C}\right)$ & ND & $15-34$ \\
\hline \multicolumn{3}{|l|}{ Salinity range $(\%)$} \\
\hline Seawater ${ }^{\text {a }}$ & ND & NG \\
\hline $\mathrm{NaCl}^{\mathrm{b}}$ & ND & $30-100$ \\
\hline $\mathrm{pH}$ range & ND & $5.9-8.6$ \\
\hline \multicolumn{3}{|l|}{ Growth on: } \\
\hline Casamino acids & ND & + \\
\hline Sucrose & - & $-{ }^{\dagger}$ \\
\hline D-Ribose & ND & $-{ }^{\dagger}$ \\
\hline DL-Aspartate & ND & - \\
\hline L-Proline & ND & - \\
\hline L-Glutamate & ND & $\mathrm{W}^{\dagger}$ \\
\hline L-Leucine & ND & - \\
\hline
\end{tabular}


Table 1. Continued...

\begin{tabular}{lcc}
\hline \multicolumn{1}{c}{ Characteristic } & Isolated strain & Tenacibaculum maritimum $(\mathbf{n}=\mathbf{2})$ \\
\hline \multicolumn{1}{c}{ Degradation of: } & & \\
Starch & - & - \\
Gelatin & + & + \\
Tween 80 & ND & + \\
Tyrosine & + & + \\
Agar & ND & - \\
Carboxymethyl cellulose & ND & - \\
Cellulose & ND & - \\
Chitin & ND & - \\
Esculin & ND & - \\
Nitrate reduction & + & + \\
H 2 production & - & -
\end{tabular}

${ }^{\mathrm{a}} 100=$ full-strength seawater; ${ }^{\mathrm{b}}$ Percentage of $\mathrm{NaCl}$ in the medium; ${ }^{\dagger}$ Data from Gosink et al. (1998); a different result was obtained by Suzuki et al. (2001); and "Data from Wakabayashi et al. (1986); a different result was obtained by Suzuki et al. (2001).

TCBS. In addition, as can be seen from Table 1, variable results have been reported for gelatine and nitrate reactions, while Avendaño-Herrera et al. (2004a) also reported difference in the hydrogen sulphide tests. These three reactions were included in Mouriño et al. and as suggested by Suzuki et al. (2001), the employment of different basal media could account for this variability.

On the other hand, as can be seen from the photomicrograph of filamentous bacteria (Figure 2, see Mouriño et al.), the spores found by these authors are not a typical characteristic of T. maritimum (Suzuki et al., 2001). In fact, Chen et al. (1995) did not observe cysts or microcysts neither from the microorganism isolated from marine fishes of California, nor from the reference strains, in contradiction with Mouriño et al. Our studies have demonstrated that the morphology of the typical slender rod shaped T. maritimum cells appear shorter and tend to become spherical, about $1 \mu \mathrm{m}$ diameter, after 3 days of incubation (Avendaño-Herrera et al., 2006b).

To date, two PCR primer pairs have been designed for the detection of T. maritimum using the $16 \mathrm{~S}$ ribosomal RNA gene as target (Toyama et al. 1996; Bader and Shotts 1998). Comparing the specificity of the 2 PCR protocols demonstrated that the sequences of both primer pairs were species-specific for T. maritimum, and no amplification products were obtained from chromosomal DNA of other non-T. maritimum (Avendaño-Herrera et al. 2004b). However, despite the potential of the PCR detection, Mouriño et al. did not test any of these primer sets. We think that these molecular tools could shed light on the confirmation of the presumptive biochemical identification of the filamentous bacterium T. maritimum in Brazil, and thus presence cannot be excluded.

\section{References}

AVENDAÑO-HERRERA, R., MAGARIÑOS, B., LÓPEZROMALDE, S., ROMALDE, JL. and TORANZO, AE., 2004a. Phenotypic characterization and description of two major O-serotypes in Tenacibaculum maritimum strains from marine fish. Diseases of Aquatic Organisms, vol. 58, no. 1, p. 1-8.

AVENDAÑO-HERRERA, R., MAGARIÑOS, B., TORANZO, AE., BEAZ, R. and ROMALDE, JL., 2004b. Species-specific polymerase chain reaction primer sets for the diagnosis of Tenacibaculum maritimum infection. Diseases of Aquatic Organisms, vol. 62, no. $1-2$, p. $75-83$.

AVENDAÑO-HERRERA, R., TORANZO, AE. and MAGARIÑOS, B., 2006a. Tenacibaculosis infection in marine fish caused by Tenacibaculum maritimum: a review. Diseases of Aquatic Organisms, vol. 71 , no. 3, p. 255-266

AVENDAÑO-HERRERA, R., IRGANG, R., MAGARIÑOS, B., ROMALDE, JL. and TORANZO, AE., 2006b. Use of microcosm to determine the survival of the fish pathogen Tenacibaculum maritimum in seawater. Environmental Microbiology, vol. 8, no. 5, p. 921-928.

BADER,JA. andSHOTTS,EB., 1998. Identification of Flavobacterium and Flexibacter species by species-specific polymerase chain reaction primers to the $16 \mathrm{~S}$ ribosomal RNA gene. Journal of Aquatic Animal Health, vol. 10, no. 4, p. 311-319.

CHEN, MF., HENRY-FORD, D. and GROFF, JM., 1995. Isolation and characterization of Flexibacter maritimus from marine fishes of California. Journal of Aquatic Animal Health, vol. 7, no. 4, p. 318-326.

GOSINK, JJ., WOESE, CR. and STALEY, JT., 1998. Polaribacter gen. Nov., with three new species, $P$. irgensii sp. nov. sp. nov., P. franzmannii sp. nov. and P. filamentous sp. nov., gas vacuolated polar marine bacteria of the Cytophaga-Flavobacterium-Bacteroides group and reclassification of 'Flectobacillus glomeratus' as Polaribacter glomeratus comb. nov. International Journal of Systematic Bacteriology, vol. 42, no. X, p. 166-170

SHEU, SY., LIN, KY., CHOU, JH., CHANG, PS., ARUN, AB., YOUNG, CC. and CHEN, WM., 2007. Tenacibaculum litopenaei sp. nov., isolated from a shrimp mariculture pond. International Journal of Systematic and Evolutionary Microbiology, vol. 57, no. 5, p. $1148-1153$

SUZUKI, M., NAKAGAWA, Y., HARAYAMA, S. and YAMAMOTO, S., 2001. Phylogenetic analysis and taxonomic study of marine Cytophaga-like bacteria: proposal for Tenacibaculum gen. nov. with Tenacibaculum maritimum comb. nov. and Tenacibaculum ovolyticum comb. nov., and description of Tenacibaculum mesophilum sp. nov. and Tenacibaculum amylolyticum sp. nov. International Journal of Systematic and Evolutionary Microbiology, vol. 51, no. 5, p. $1639-1652$

TOYAMA, T., KITA-TSUKAMOTO, K. and WAKABAYASHI, H., 1996. Identification of Flexibacter maritimus, Flavobacterium branchiophilum and Cytophaga columnaris by PCR targeted $16 \mathrm{~S}$ ribosomal DNA. Fish Pathology, vol. 31, no. 1, p. 25-31.

WAKABAYASHI, H., HIKIDA, M. and MASUMURA, K., 1986. Flexibacter maritimus sp. nov., a pathogen of marine fishes. International Journal of Systematic Bacteriology, vol. 36, no. 3, p. 396-398. 